\title{
Population structure of striped marlin (Kajikia audax) in the Pacific Ocean based on analysis of microsatellite and mitochondrial DNA
}

\author{
Jan R. McDowell and John E. Graves
}

\begin{abstract}
Genetic variation was surveyed at five microsatellite loci and the mitochondrial control region (819 bp) to test for the presence of genetic stock structure in striped marlin (Kajikia audax) collections taken from seven locations throughout the Pacific Ocean. Temporal replicates separated by 9 years were taken off Japan, and three temporal samples spanning 11 years were collected off the coast of eastern Australia. Analyses of multilocus microsatellite genotypes and mitochondrial control region sequences showed no significant heterogeneity among collections taken from the same location in different years; however, significant spatial genetic heterogeneity was observed across all samples for microsatellite markers $\left(F_{\mathrm{ST}}=0.013, P<0.001\right)$. Mitochondrial control region sequences were not different across all samples $\left(\Phi_{\mathrm{ST}}=-0.01, P=\right.$ 0.642). Analyses of molecular variance (AMOVA) revealed significant genetic differentiation between geographic regions for both microsatellite and mitochondrial markers. These results suggest the presence of genetically discrete populations within the Pacific Ocean and are supported by both the results of tagging studies, which show limited dispersal, and the presence of geographically separated spawning grounds.
\end{abstract}

Résumé : Nous avons analysé la variation génétique à cinq locus microsatellites et dans la région mitochondriale de contrôle $(819 \mathrm{pb})$ pour vérifier la présence de structure génétique dans des échantillons de stocks de marlins rayés (Kajikia audax) provenant de sept sites répartis dans tout le Pacifique. Nous avons pris des échantillons temporels à un intervalle de 9 années au large du Japon et trois échantillons temporels sur une période de 11 ans au large de la cōte de l'Australie orientale. Des analyses des génotypes à locus microsatellites multiples et des séquences de la région mitochondriale de contrôle n'indiquent aucune hétérogénéité significative entre les récoltes prises au même site durant des années différentes; on observe, cependant, une hétérogénéité génétique spatiale significative parmi l'ensemble des échantillons chez les marqueurs microsatellites $\left(F_{\mathrm{ST}}=0,013, P<0,001\right)$. Les séquences des régions mitochondriales de contrôle ne diffèrent pas dans l'ensemble des échantillons $\left(\Phi_{\mathrm{ST}}=-0,01, P=0,642\right)$. Des analyses de la variance moléculaire (AMOVA) montrent une différenciation génétique significative entre les régions géographiques, tant chez les marqueurs microsatellites que mitochondriaux. Ces résultats font croire à l'existence de populations génétiquement distinctes au sein du Pacifique, ce qui est corroboré à la fois par les résultats des études de marquage qui révèlent une dispersion limitée et par la présence de sites de fraie séparés géographiquement.

[Traduit par la Rédaction]

\section{Introduction}

The factors leading to population structure in large pelagic species, such as istiophorid billfishes, have been subject to much speculation. Unlike less mobile organisms, pelagic species have a vast potential for dispersal and a lack of apparent physical barriers (Graves 1998). In theory, these factors are thought to preclude the development of population genetic structure (Waples 1998; Smedbol et al. 2002). In addition, information that has traditionally been used to appraise the presence of distinct stocks in other marine fishes, such as where and when they spawn, preferred mi-

Received 25 April 2007. Accepted 6 December 2007. Published on the NRC Research Press Web site at cjfas.nrc.ca on 21 May 2008.

J19940

J.R. McDowell ${ }^{\mathbf{1}}$ and J.E. Graves. Virginia Institute of Marine Science, School of Marine Science, College of William and Mary, Rt. 1208, Greate Road, Gloucester Point, VA 23062-1346, USA.

${ }^{1}$ Corresponding author (e-mail: mcdowell@vims.edu). gratory routes, and what comprises suitable habitat, is limited for istiophorid billfishes, making it difficult to assess population structure (Graves and McDowell 2003).

Members of the Istiophoridae, which include the marlins, spearfishes, and sailfish (Istiophorus platypterus), generally exhibit limited genetic structure between geographically disjunct samples. The black marlin (Istiompax indica) showed no evidence of spatially structured populations between samples collected from throughout the Indo-Pacific (Australia, Vietnam, South Africa, Taiwan, and the eastern Pacific) using either five tetranucleotide microsatellites or restriction fragment length polymorphism (RFLP) analysis of the mitochondrial control region (Falterman 1999). Similarly, the blue marlin (Makaira nigricans) showed no evidence of population structure within either the Atlantic or Indo-Pacific oceans based on either nuclear (allozymes, anonymous single copy nuclear DNA), or mitochondrial DNA markers (Graves and McDowell 1995, 2003; Buonaccorsi et al. 1999). However, there were distinct differences between collections of blue marlin from different ocean basins resulting from differences in the distribution of two evolutionarily distinct mitochondrial lineages (Finnerty and 
Fig. 1. Distribution of striped marlin (Kajikia audax) in the Pacific Ocean as indicated by mean annual Japanese longline catch per unit effort (CPUE) for the period 1970-2000. Hatched boxes indicate identified spawning grounds based on the presence of larvae (reproduced from Bromhead et al. 2004). Collection locations are noted.

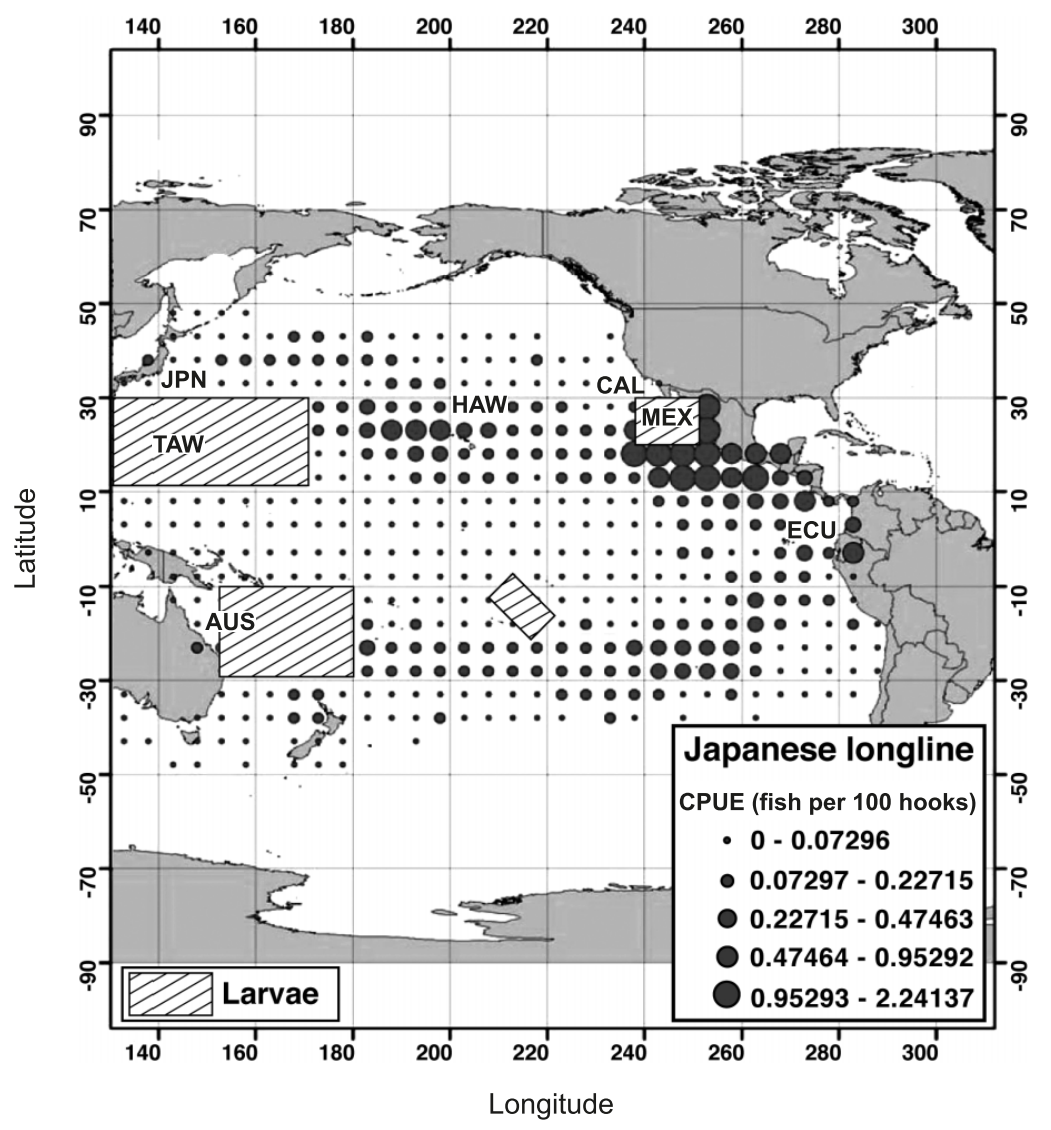

Block 1992; Graves and McDowell 1995; Buonaccorsi et al. 2001). Within the Kajikia, whole molecule mtDNA RFLP analysis of the white marlin (Kajikia albidus) showed no evidence of population structure in the Atlantic among samples taken from the US east coast, the Caribbean, Brazil, and Morocco (Graves and McDowell 2001, 2006).

The striped marlin (Kajikia audax) is the most widely distributed (latitudinally) of the billfish species, occurring throughout the tropical, subtropical, and temperate waters of the Pacific and Indian oceans (Nakamura 1985), with occasional observations reported from the Atlantic Ocean near the Cape of Good Hope (Talbot and Penrith 1962; Penrith and Cram 1974). In the Pacific Ocean, striped marlin is distributed between about $45^{\circ} \mathrm{N}$ and $45^{\circ} \mathrm{S}$. Fishery data suggests a horseshoe-shaped distribution across the central North and central South Pacific, with a continuous distribution along the west coast of Central America (Nakamura 1985; Fig. 1). Abundances of striped marlin are highest in the central North Pacific and the eastern tropical Pacific as compared with the southern and western Pacific based on longline data (Ueyanagi and Wares 1975). Pacific striped marlin generally occur between the 20 and $25{ }^{\circ} \mathrm{C}$ degree surface isotherms and prefer more temperate waters than other billfishes, which are tropically and subtropically distributed (Nakamura 1985). Striped marlin larvae are primarily found during the late spring and early summer in both hemispheres of the Pacific (Nakamura 1983) and occur in four spatially discrete regions: the eastern North Pacific, the eastern South Pacific, the western North Pacific, and the central South Pacific, suggesting the potential for spawning site fidelity (Fig. 1).

Striped marlin represent an important commercial and recreational resource throughout its range, with the largest catches taken as bycatch by the pelagic longline fisheries targeting tunas (Thunnus spp.) (Hinton and Maunder 2003). It has been estimated that $90 \%$ of the global commercial catch of billfishes are taken by fisheries targeting other species (King 1990). Pacific-wide landings of striped marlin average around $12000 \mathrm{t}$ and represent $86 \%$ of world landings (Southwest Fisheries Science Center, La Jolla, California). The status of striped marlin as a bycatch species, despite its importance as a recreational species, has resulted in a lack of basic information necessary for effective fishery management, including knowledge of the number of independent stocks and their boundaries (Hinton and Maunder 2003). The inability of traditional fisheries data to resolve the population structure of striped marlin has hindered accurate assessment of the status of striped marlin stocks (Skillman 1990).

In contrast with other billfish species, previous genetic studies of striped marlin have indicated heterogeneity among Pacific striped marlin collections. Allozyme analysis found slight but statistically significant differences among striped marlin samples from Mexico, Ecuador, Australia, and Hawaii in the Pacific (Morgan 1992). Similarly, in an analysis of whole molecule mitochondrial DNA based on RFLP anal- 
ysis using 11 restriction endonucleases from the same samples, several mtDNA haplotypes were present at elevated frequencies within the geographic regions when samples were grouped into eastern, western, and central Pacific regions, while other haplotypes appeared to differentiate individual collections within geographic regions (Graves and McDowell 1994). However, as most haplotypes differed by less than three restriction site changes, net nucleotide sequence divergences $(\pi)$ between collections were very low $(0.01 \%-0.06 \%)$. One major limitation of these studies was the absence of temporal replicates, making the significance of observed differences difficult to evaluate.

The results of previous genetic studies combined with the presence of spatially distinct spawning grounds and the results of tagging studies that suggesting limited dispersal (summarized in Ortiz et al. 2003) have led researchers to postulate that striped marlin do not comprise a single stock in the Pacific Ocean. Furthermore, the lack of large-scale annual movement of large numbers of striped marlin has led to the assertion that striped marlin are much less migratory than previously thought, suggesting that striped marlin are not strictly "highly migratory" like other marlin and tunas (summarized in Bromhead et al. 2004). If the presence of four spatially discrete spawning locations in the Pacific Ocean are driven by (or are a result of) the existence of separate stocks, genetic analysis of striped marlin taken from throughout their range should reveal the presence at least four distinct genetic stocks and confirm the results of earlier studies suggesting spatially structured populations. To test this hypothesis, 373 striped marlin from seven collection locations were screened for genetic variability at five microsatellite loci, and a subset of 85 individuals were sequenced at the mitochondrial DNA control region. In addition, temporal stability of genetic variation was evaluated in collections of striped marlin from Australia and Japan.

\section{Materials and methods}

\section{Biological materials}

Striped marlin samples were collected from commercial, artisanal, and recreational fisheries at seven sites throughout the Pacific Ocean over a 14-year period $(n=373)$. Locations included Taiwan (TAW) and Japan (JPN) in the northwest Pacific; Port Stephens, Australia (AUS) in the southwest Pacific; Kona, Hawaii (HAW) in the central North Pacific; Cabo San Lucas, Mexico (MEX) and San Diego, California (CAL) in the northeast Pacific; and Manta, Ecuador (ECU) in the southeast Pacific. Replicate samples were collected from JPN in 1994 and 2003 and from AUS in 1994, 1996, and 2005 (Fig. 1, Table 1).

\section{DNA isolation}

Samples consisted of either heart tissue removed after capture and stored at $-80{ }^{\circ} \mathrm{C}$ until isolation or white muscle preserved in $0.25 \mathrm{mmol} \cdot \mathrm{L}^{-1}$ ethylenediaminetetraacetic acid (EDTA) $\mathrm{pH}$ 8.0, 20\% dimethyl sulfoxide (DMSO), and saturated $\mathrm{NaCl}$ (Seutin et al. 1991) at room temperature until isolation. DNA was isolated using either a phenol-chloroform (Sambrook and Russell. 2001) or a proteinase K - chelex extraction (Estoup et al. 1996).

\section{Microsatellites}

Five microsatellite loci originally developed for use in the blue marlin (Mn01, Mn08, Mn10, Mn60, and Mn90) were amplified using the parameters outlined in Buonaccorsi and Graves (2000). Microsatellite loci were analyzed on a LICOR 4200 Global IR ${ }^{2}$ automated sequencer (LI-COR Inc., Lincoln, Nebraska, USA). A 50-350 base pair (bp) size standard (LI-COR) was loaded onto each end and at the center of each gel to determine allele sizes. To ensure identical scoring of alleles at a locus across gels, between four and eight lanes of each run consisted of samples for which allele sizes were known. Alleles sizes were measured using the Gene ImagIR 4.03 software (LI-COR). Approximately 20\% of the samples were measured twice to verify that alleles could be consistently scored.

The MICRO-CHECKER 2.2.1 software (van Oosterhout et al. 2004) was used to identify possible genotyping errors such as stuttering, large allele dropout, and null alleles within the microsatellite data set by performing 10000 randomizations. GENEPOP 3.1b (Raymond and Rousset 1995) was used to perform exact tests (10 000 iterations; Guo and Thompson 1992) for deviations of genotypic distributions from the expectations of Hardy-Weinberg equilibrium and to calculate observed $\left(H_{\mathrm{O}}\right)$ and expected $\left(H_{\mathrm{E}}\right)$ heterozygosities and test for heterozygote excess and deficiencies in the microsatellite data. The program FSTAT 2.9.3 (Goudet 1995) was used to estimate allelic richness per locus and sample $\left(R_{\mathrm{s}}\right)$ to allow comparison of the number of alleles independent of samples size for microsatellite data.

The ARLEQUIN software package (Excoffier et al. 2005) was used to estimate Weir and Cockerham's (1984) unbiased estimator of Wright's $F$ statistics $\left(F_{\mathrm{ST}}\right)$ and for hierarchical $F_{\mathrm{ST}}$ analyses (analysis of molecular variance, AMOVA, 10100 permutations) on microsatellite data. A principal component analysis (PCA) was performed on the multilocus microsatellite data using the program PCAGEN (J. Goudet, Institute of Ecology, Université de Lausanne, CH-1015, Lausanne, Switzerland, www2.unil.ch/popgen/ softwares/pcagen.htm). Populations were ordinated according to the first and second axes. The percent inertia of each PCA axis and its $P$ value were assessed by performing 10000 randomizations of genotypes.

The program MIGRATE (Beerli and Felsenstein 2001; Beerli 2002) was used to estimate both theta $(\Theta)$, which is equal to $4 N_{\mathrm{e}} \mu$ (where $N_{\mathrm{e}}$ is the long-term (inbreeding) effective population size, and $\mu$ is the mutation rate) and $M$, which is equal to the ratio $m / \mu$ (where $m$ is the immigration rate). Analyses were performed under the allele model, as not all microsatellite loci conformed to the strict expectations of the stepwise mutation model (i.e., there were missing steps in the distribution of alleles for some loci). Each Markov chain Monte Carlo (MCMC) run consisted of 10 short chains (sampling 10000 trees) and three long chains (sampling 100000 trees) with a burn-in period of 10000 trees. All runs were repeated five times to verify consistency of results, and the data presented are the average of the five runs.

\section{Control region}

Subsets of 12 individuals from each of the sampling locations were sequenced for an 819 bp fragment of the mito- 
Table 1. Summary statistics for five microsatellite loci among striped marlin (Kajikia audax) samples.

\begin{tabular}{|c|c|c|c|c|c|c|}
\hline \multirow[b]{2}{*}{ Sample } & \multicolumn{5}{|l|}{ Locus } & \multirow[b]{2}{*}{$\begin{array}{l}\text { Average } \\
\text { across loci }\end{array}$} \\
\hline & $\mathrm{MnO1}$ & MnO8 & Mn10 & Mn60 & $M n 90$ & \\
\hline \multicolumn{7}{|l|}{ AUS 1994} \\
\hline$n$ & 37 & 37 & 37 & 37 & 37 & \\
\hline$a$ & 9 & 20 & 12 & 23 & 25 & \\
\hline$R_{\mathrm{S}}$ & 7.93 & 17.25 & 11.08 & 19.54 & 21.50 & 15.46 \\
\hline RPT range & $14-22$ & $7-35$ & $7-24$ & $12-38$ & $22-88$ & \\
\hline$H_{\mathrm{E}}$ & 0.77 & 0.93 & 0.89 & 0.94 & 0.95 & 0.896 \\
\hline$H_{\mathrm{O}}$ & 0.78 & 0.92 & 0.94 & 0.95 & 0.97 & 0.912 \\
\hline HW & 0.359 & 0.323 & 0.392 & 0.972 & 0.979 & \\
\hline \multicolumn{7}{|l|}{ AUS 1996} \\
\hline$n$ & 27 & 27 & 27 & 27 & 27 & \\
\hline$a$ & 8 & 19 & 9 & 18 & 22 & \\
\hline$R_{\mathrm{s}}$ & 7.88 & 18.49 & 8.99 & 17.18 & 21.15 & 14.74 \\
\hline RPT range & $14-22$ & $7-33$ & $11-21$ & $14-37$ & 46-90 & \\
\hline$H_{\mathrm{E}}$ & 0.81 & 0.94 & 0.84 & 0.93 & 0.95 & 0.894 \\
\hline$H_{\mathrm{O}}$ & 0.67 & 0.96 & 0.78 & 0.93 & 0.96 & 0.860 \\
\hline HW & 0.589 & 0.729 & 0.383 & 0.383 & 0.938 & \\
\hline \multicolumn{7}{|l|}{ AUS 2005} \\
\hline$n$ & 33 & 33 & 33 & 33 & 33 & \\
\hline$a$ & 11 & 20 & 14 & 20 & 26 & \\
\hline$R_{\mathrm{s}}$ & 10.2 & 18.89 & 12.54 & 18.55 & 24.16 & 16.87 \\
\hline RPT range & $14-35$ & $7-32$ & $7-21$ & $12-41$ & $42-88$ & \\
\hline$H_{\mathrm{E}}$ & 0.84 & 0.87 & 0.87 & 0.95 & 0.84 & 0.874 \\
\hline$H_{\mathrm{O}}$ & 0.91 & 0.88 & 0.85 & 0.85 & 0.82 & 0.862 \\
\hline HW & 0.711 & 0.868 & 0.427 & 0.200 & 0.664 & \\
\hline \multicolumn{7}{|l|}{ CAL 2000} \\
\hline$n$ & 39 & 39 & 39 & 39 & 39 & \\
\hline$a$ & 9 & 22 & 14 & 23 & 24 & \\
\hline$R_{\mathrm{s}}$ & 8.60 & 18.33 & 12.09 & 20.51 & 19.91 & 15.89 \\
\hline RPT range & $14-22$ & $10-35$ & $7-22$ & $12-52$ & 22-90 & \\
\hline$H_{\mathrm{E}}$ & 0.853 & 0.937 & 0.884 & 0.952 & 0.938 & 0.913 \\
\hline$H_{\mathrm{O}}$ & 0.795 & 0.923 & 0.897 & 0.923 & 0.923 & 0.982 \\
\hline HW & 0.326 & 0.447 & 0.878 & 0.550 & 0.186 & \\
\hline \multicolumn{7}{|l|}{ ECU 1995} \\
\hline$n$ & 39 & 39 & 39 & 39 & 39 & \\
\hline$a$ & 8 & 22 & 15 & 25 & 22 & \\
\hline$R_{\mathrm{S}}$ & 7.73 & 18.50 & 12.44 & 20.06 & 18.60 & 15.46 \\
\hline RPT range & $14-21$ & $10-38$ & $7-24$ & $14-51$ & 46-90 & \\
\hline$H_{\mathrm{E}}$ & 0.775 & 0.935 & 0.871 & 0.941 & 0.941 & 0.893 \\
\hline$H_{\mathrm{O}}$ & 0.795 & 0.949 & 0.846 & 0.974 & 0.974 & 0.908 \\
\hline HW & 0.471 & 0.331 & 0.004 & 0.682 & 0.864 & \\
\hline \multicolumn{7}{|l|}{ НАW 1998} \\
\hline$n$ & 48 & 48 & 48 & 48 & 48 & \\
\hline$a$ & 10 & 23 & 14 & 27 & 23 & \\
\hline$R_{\mathrm{S}}$ & 8.19 & 18.84 & 12.60 & 20.97 & 19.00 & 15.92 \\
\hline RPT range & $14-39$ & $3-37$ & $7-22$ & $12-53$ & 30-90 & \\
\hline$H_{\mathrm{E}}$ & 0.837 & 0.947 & 0.891 & 0.955 & 0.931 & 0.745 \\
\hline$H_{\mathrm{O}}$ & 0.75 & 0.937 & 0.937 & 0.875 & 0.771 & 0.854 \\
\hline HW & 0.110 & 0.325 & 0.503 & 0.380 & 0.186 & \\
\hline
\end{tabular}


Table 1 (concluded).

\begin{tabular}{|c|c|c|c|c|c|c|}
\hline \multirow[b]{2}{*}{ Sample } & \multicolumn{5}{|l|}{ Locus } & \multirow{2}{*}{$\begin{array}{l}\text { Average } \\
\text { across loc }\end{array}$} \\
\hline & $\mathrm{MnO1}$ & Mn08 & Mn10 & Mn60 & $M n 90$ & \\
\hline \multicolumn{7}{|l|}{ MEX 1994} \\
\hline$n$ & 32 & 32 & 32 & 32 & 32 & \\
\hline$a$ & 7 & 20 & 11 & 18 & 20 & \\
\hline$R_{\mathrm{S}}$ & 6.98 & 18.43 & 9.90 & 16.95 & 17.84 & 14.02 \\
\hline $\mathrm{RPT}$ range & $15-21$ & $10-38$ & $7-21$ & $14-55$ & $52-86$ & \\
\hline$H_{\mathrm{E}}$ & 0.83 & 0.936 & 0.734 & 0.936 & 0.935 & 0.874 \\
\hline$H_{\mathrm{O}}$ & 0.781 & 0.906 & 0.844 & 0.937 & 0.969 & 0.887 \\
\hline HW & 0.140 & 0.296 & 0.252 & 0.478 & 0.315 & \\
\hline \multicolumn{7}{|l|}{ TAW 1998} \\
\hline$n$ & 24 & 24 & 24 & 24 & 24 & \\
\hline$a$ & 8 & 17 & 12 & 14 & 19 & \\
\hline$R_{\mathrm{S}}$ & 8 & 17 & 12 & 14 & 19 & 14 \\
\hline RPT range & $10-20$ & $12-34$ & $7-22$ & $14-33$ & $46-90$ & \\
\hline$H_{\mathrm{E}}$ & 0.825 & 0.941 & 0.891 & 0.906 & 0.945 & 0.902 \\
\hline$H_{\mathrm{O}}$ & 0.667 & 0.958 & 0.875 & 0.792 & 0.917 & 0.842 \\
\hline HW & 0.106 & 0.983 & 0.447 & 0.191 & 0.555 & \\
\hline \multicolumn{7}{|l|}{ JPN 1994} \\
\hline$n$ & 39 & 39 & 39 & 39 & 39 & \\
\hline$a$ & 11 & 26 & 18 & 24 & 28 & \\
\hline$R_{\mathrm{S}}$ & 10.00 & 19.44 & 11.90 & 18.88 & 18.05 & 15.67 \\
\hline $\mathrm{RPT}$ range & $10-22$ & $7-34$ & $7-22$ & $12-38$ & $45-88$ & \\
\hline$H_{\mathrm{E}}$ & 0.864 & 0.945 & 0.881 & 0.942 & 0.935 & 0.913 \\
\hline$H_{\mathrm{O}}$ & 0.795 & 1 & 0.897 & 0.974 & 0.923 & 0.918 \\
\hline HW & 0.176 & 0.976 & 0.056 & 0.128 & 0.848 & \\
\hline \multicolumn{7}{|l|}{ JPN 2003} \\
\hline$n$ & 53 & 53 & 53 & 53 & 53 & \\
\hline$a$ & 9 & 26 & 17 & 22 & 25 & \\
\hline$R_{\mathrm{S}}$ & 8.04 & 20.50 & 13.94 & 18.65 & 19.21 & 16.07 \\
\hline $\mathrm{RPT}$ range & $10-21$ & $7-36$ & $7-31$ & $12-35$ & 46-94 & \\
\hline$H_{\mathrm{E}}$ & 0.801 & 0.952 & 0.89 & 0.943 & 0.943 & 0.906 \\
\hline$H_{\mathrm{O}}$ & 0.623 & 0.943 & 0.849 & 0.887 & 0.962 & 0.853 \\
\hline HW & 0.006 & 0.887 & 0.053 & 0.005 & 0.957 & \\
\hline
\end{tabular}

Note: AUS, Australia; CAL, California; ECU, Ecuador; HAW, Hawaii; MEX, Mexico; TAW, Taiwan; JPN, Japan; $n$, number of individuals; $a$, number of alleles; $R_{\mathrm{s}}$, allelic richness per locus and sample; RPT range, size range in number of repeats; $H_{\mathrm{E}}$, expected heterozygosity; $H_{\mathrm{O}}$, observed heterozygosity; $\mathrm{HW}$, probability of concordance with Hardy-Weinberg expectations. Values in bold are significant after correction for multiple tests (initial $\alpha=0.05 / 5=0.01$ ).

chondrial control region, with the exception of individuals from the CAL sample, which failed to amplify (85 individuals were sequenced, GenBank accession Numbers DQ199950-DQ200028). Samples were amplified using the Pro-5' and 12SAR-3' primers (Palumbi et al. 1996; CACGACGTTGTAAAACGACCTACCYCYAACTCCCAAAGC and GGATAACAATTTCACACAGGGCATAGTGGGGTATCTAATCC, respectively). Primers were modified to include M13 tails. Amplified products were sequenced on a LI-COR 4200 Global IR ${ }^{2}$ system using IRD-800-labelled forward primer and IRD-700-labelled reverse primer (LICOR). M13F (-29) and an internal reverse primer designed specifically for the teleost control region (CCATCTTAACATCTTCAGTG; S. Boles, Virginia Institute of Marine Science, Rt 1208 Greate Road, Gloucester Point, VA 23062, USA, unpublished data) were used for sequencing.
Standard chromatographic curves of forward and reverse sequences were imported into the program Sequencher 4.2.2 (Gene Codes Corp., Ann Arbor, Michigan, USA), aligned, and edited. A consensus of forward and reverse sequences was created and exported to the program MacVector 7.2.3 (Oxford Molecular LTD, Madison, Wisconsin, USA), and an alignment was created using the CLUSTAL W algorithm (Thompson et al. 1994) and adjusted by eye.

The ARLEQUIN software package (Excoffier et al. 2005) was used to estimate $\Phi_{\mathrm{ST}}$ (an mtDNA analogue for $F_{\mathrm{ST}}$; Excoffier et al. 1992) and for hierarchical $\Phi_{\mathrm{ST}}$ analyses on control region sequences as described above. The $\Phi_{\mathrm{ST}}$ analyses were performed using a matrix of Tamura and Nei (1993) distances. The program ARLEQUIN (Excoffier et al. 2005) was also used to calculate haplotype diversity $(h)$ and nucleotide diversity $(\pi)$ for the mtDNA control region se- 
quence data. PAUP* 4.0 (Swofford 2000) was used to generate the table of variable sites and a neighbor-joining (Saitou and Nei 1987) tree based on the Tamura-Nei distance (Tamura and Nei 1993; Fig. 2). DnaSP 4.0 (Rozas et al. 2003) was used to estimate the nearest-neighbor statistic, $S_{\mathrm{nn}}$ (Hudson 2000), for the mtDNA control region sequences using 10000 permutations and gaps excluded in pairwise comparisons. The $S_{\text {nn }}$ statistic measures how often the nearest neighbors in sequence space are from the same locality in geographical space and is particularly appropriate when $h$ is large and sample sizes are small (Hudson 2000). Significance levels were adjusted using the sequential Bonferroni technique (Rice 1989) in all cases of multiple tests.

\section{Results}

\section{Genetic variation}

For microsatellite data, the number of alleles per locus varied from 7 at locus $\mathrm{MnOl}$ to 27 at locus $\mathrm{Mn} 60$ (Table 1). Allelic richness per locus and sample ranged from 6.98 at locus $\mathrm{MnO1}$ in the MEX 1994 sample to 24.16 in the AUS 2005 sample at locus $M n 90$; the average across loci ranged from 14 in TAW 1998 to 16.87 in AUS 2005 (Table 1). Average observed heterozygosities ranged from 0.67 at locus $\mathrm{MnOl}$ in the AUS 1996 and TAW 1998 samples to 0.97 at the Mn60 (ECU 1995 and JPN 1994) and Mn90 (AUS 1994, ECU 1995, MEX 1994) loci; the average across loci ranged from 0.84 in TAW 1998 to 0.913 in CAL 2000 (Table 1). Average expected heterozygosities ranged from 0.73 in the MEX 1994 sample at Mn10 to 0.96 in the HAW 1998 sample at $M n 60$ and from 0.74 for HAW 1998 to 0.91 for CAL 2000 and JPN 1994 (Table 1). Three of the 50 tests for conformance to the expectations to Hardy-Weinberg equilibrium differed significantly after corrections for multiple tests. The ECU 1995 sample had a genotypic distribution that differed significantly at $M n 10$, and the JPN 2003 sample differed at MnO1 and Mn60 (heterozygote deficits; Table 1). Analysis with the MICROCHECKER software showed no evidence that null alleles, stuttering, or large allele dropout affected any of the loci, and rescoring of samples confirmed that alleles were being sized consistently across gels; consequently, all loci were included in all analyses.

Aligned mitochondrial control region sequences ranged from 781 to $807 \mathrm{bp}$, excluding gaps. Overall, 570 characters were constant, 249 were variable, and 58 insertions-deletions were observed. Of the 249 variable sites, 162 were parsimony informative. For mtDNA, there were 79 haplotypes detected among the 83 striped marlin sequenced at the control region, and no haplotype was detected more than twice. Among the four haplotypes that were shared, one was common to two JPN samples, one occurred in JPN and TAW, one in JPN and HAW, and one in HAW and MEX (Fig. 2). Haplotype diversity $(h)$ was 0.998 over all samples and ranged from 0.98 to 1.0 . Nucleotide diversity $(\pi)$ was $0.044 \pm 0.021$ over all samples and ranged from $0.039 \pm 0021$ in the AUS sample to $0.054 \pm 0.029$ in the TAW sample.

\section{Population structure based on microsatellites}

The presence of temporal stability of the AUS (1994, 1996, 2005) and JPN (1994, 2003) samples was assessed us- ing pairwise multilocus $F_{\mathrm{ST}}$ values (10 000 permutations of the data). In addition, an AMOVA was conducted for the three AUS samples. The $F_{\mathrm{ST}}$ between the two JPN samples was $-0.0001(P=0.540) . F_{\mathrm{ST}}$ values for the three Australian samples ranged from $-0.0035(P=0.872)$ between AUS 1994 and AUS 2005 to $0.0047(P=0.093)$ between AUS 1996 and AUS 2005; no values were significant. An AMOVA among the AUS collections indicated that only $0.12 \%$ of the variation was among samples $(P=0.252$, Table 2) while $99.88 \%$ was within samples.

To examine whether results of multilocus $F_{\mathrm{ST}}$ analyses were being driven by a single locus, population pairwise $F_{\text {ST }}$ values were calculated separately for each locus. In population pairwise $F_{\mathrm{ST}}$ comparisons across all loci, 18/21 (85.7\%) were significant $(P<0.05$, data not shown), and results for individual loci ranged from 8/21 (38\%) for Mn60 to $14 / 21(66.7 \%)$ for $M n 01$. The global multilocus $F_{\mathrm{ST}}$ across all samples was $0.013(P<0.001)$, and single locus values ranged from 0.0336 at $\mathrm{MnO1}$ to 0.0067 at $\mathrm{Mn} 90$; all values were highly significant $(P<0.001)$.

Since there was no evidence of temporal variation among samples in the microsatellite data, the temporal replicate collections were pooled for subsequent analyses. The global $F_{\text {ST }}$ among all samples was $0.0134(P<0.001)$. Pairwise multilocus $F_{\mathrm{ST}}$ values ranged from $0.0004(P=0.435)$ between CAL and JPN to $0.0276(P<0.001)$ between MEX and AUS; in general, $F_{\mathrm{ST}}$ values were highest between the MEX sample and all other locations (Table 3). AMOVAs were performed to maximize the amount of variance due to variation among groups of samples (regions). Since the JPN, HAW, and CAL samples were not significantly different in pairwise comparisons (Table 3), they were grouped together for AMOVA analysis and collectively designated "northern" resulting in an $F_{\mathrm{ST}}$ of $0.002(P=0.089)$. Addition of TAW to the northern sample resulted in an $F_{\mathrm{ST}}$ of $0.004(P=0.005)$, a small but significant difference among collections within the group. Grouping samples into strictly northern (JPN, TAW, HAW, CAL) and southern (AUS, ECU, MEX) groups revealed small but significant spatial differences among regions $\left(F_{\mathrm{CT}}=0.004, P<0.001\right)$. However, grouping samples into strictly east (JPN, TAW, AUS) and west (CAL, MEX, ECU) collections revealed no significant spatial differentiation among the samples $\left(F_{\mathrm{CT}}=-0.002, P=0.696\right)$. Differences among regions $(\%$ variation and fixation index) were maximized and variation within regions was minimized when the northern collection was grouped and all remaining collections (AUS, MEX, ECU) were held separately $\left(F_{\mathrm{CT}}=0.014, P<0.0001\right)$. Likewise, the PCA analysis (Fig. 3) indicated that the JPN, TAW, CAL, and HAW composed a single (northern) group, while the AUS, MEX, and ECU collections appeared to represent distinct groups. The two principal axes together explained $50.67 \%$ of the total genetic diversity. The first principal component explained $29.81 \%(P<0.001)$ of the variance among the populations, and the second axis accounted for $20.86 \%$ of the variance $(P<0.001)$. The third component accounted for $11.84 \%$ of the variance and was not significant $(P=0.989)$.

\section{Population structure based on mtDNA}

Unlike results from the microsatellite markers, there were 
Fig. 2. Neighbour-joining tree of striped marlin (Kajikia audax) mitochondrial control region sequences (819 bp) based on the Tamura and Nei (1993) distances. Sample designations are as follows: Japan, Jpn; Taiwan, Taw; Australia, Aus; Hawaii, Haw; California, Cal; Mexico, Mex; and Ecuador, Ecu.

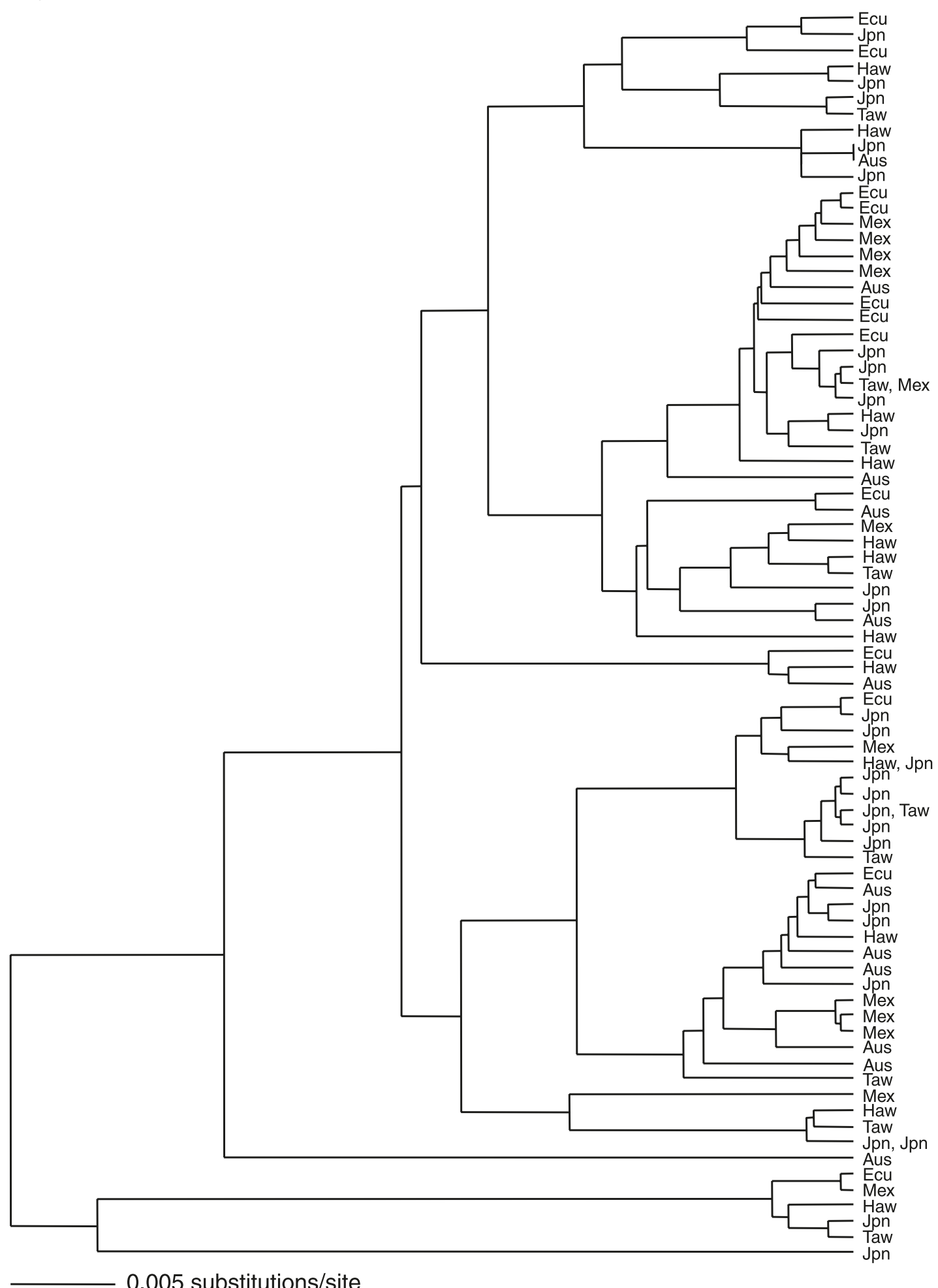

no significant pairwise comparisons of $\Phi_{\mathrm{ST}}$ based on Tamura-Nei distances (Tamura and Nei 1993). Values ranged from -0.0587 between HAW and TAW to 0.0430 between ECU and AUS. However, the nearest-neighbor statistic $\left(S_{\mathrm{nn}}\right)$ revealed a significant, nonrandom association be- tween mtDNA sequence similarity and geographic location $\left(S_{\mathrm{nn}}=0.202, P<0.0001\right)$. An AMOVA indicated that population divisions were essentially the same as those obtained from microsatellite data. Grouping the JPN, TAW, and HAW collections into the northern group and holding all 
Table 2. Analysis of molecular variance (AMOVA) among regions and locations for striped marlin (Kajikia audax) based on the number of alleles $\left(F_{\mathrm{ST}}\right)$ for microsatellite data.

\begin{tabular}{|c|c|c|c|c|}
\hline & Source of variation $\left(F_{\mathrm{ST}}\right)$ & $\%$ variation & $\begin{array}{l}\text { Fixation } \\
\text { index }\end{array}$ & $P$ \\
\hline \multicolumn{5}{|l|}{ Samples } \\
\hline \multirow[t]{2}{*}{ All samples } & Among samples & 1.35 & 0.013 & $<0.0001$ \\
\hline & Within samples & 98.65 & & \\
\hline \multirow{2}{*}{$\begin{array}{l}\text { Temporal stability } \\
\text { (AUS 1994, 1996, 2005) }\end{array}$} & Among samples & 0.12 & 0.001 & 0.252 \\
\hline & Within samples & 99.88 & & \\
\hline \multirow{2}{*}{$\begin{array}{l}\text { Temporal stability } \\
\text { (JPN 1994, 2003) }\end{array}$} & Among samples & -0.01 & 0.000 & 0.543 \\
\hline & Within samples & 100.01 & & \\
\hline \multirow{2}{*}{$\begin{array}{l}\text { North } \\
\text { (JPN, HAW, CAL) }\end{array}$} & Among samples & 0.20 & 0.002 & 0.089 \\
\hline & Within samples & 99.80 & & \\
\hline \multirow{2}{*}{$\begin{array}{l}\text { North } \\
\text { (JPN, TAW, HAW, CAL) }\end{array}$} & Among samples & 0.40 & 0.004 & 0.005 \\
\hline & Within samples & 99.60 & & \\
\hline \multirow{2}{*}{$\begin{array}{l}\text { South } \\
\text { (AUS, ECU, MEX) }\end{array}$} & Among samples & 2.03 & 0.020 & $<0.0001$ \\
\hline & Within samples & 97.97 & & \\
\hline \multirow{2}{*}{$\begin{array}{l}\text { South } \\
\text { (AUS, ECU, MEX, TAW) }\end{array}$} & Among samples & 2.13 & 0.021 & $<0.0001$ \\
\hline & Within samples & 97.87 & & \\
\hline \multirow{3}{*}{$\begin{array}{l}\text { North and South } \\
\text { (North: HAW, JPN, TAW, CAL; } \\
\text { South: AUS, ECU, MEX) }\end{array}$} & Among regions & 0.50 & 0.004 & $<0.0001$ \\
\hline & Among populations and regions & 1.05 & 0.011 & $<0.0001$ \\
\hline & Within populations & 98.45 & 0.015 & $<0.0001$ \\
\hline \multirow{3}{*}{$\begin{array}{l}\text { North and South } \\
\text { (North: HAW, JPN, CAL; } \\
\text { South: AUS, ECU, MEX, TAW) }\end{array}$} & Among regions & 0.22 & 0.002 & 0.210 \\
\hline & Among populations and regions & 1.22 & 0.012 & $<0.0001$ \\
\hline & Within populations & 98.56 & 0.014 & $<0.0001$ \\
\hline \multirow{3}{*}{$\begin{array}{l}\text { East and West } \\
\text { (East: JPN, TAW, AUS; } \\
\text { West: CAL, MEX, ECU) }\end{array}$} & Among regions & -0.15 & -0.002 & 0.696 \\
\hline & Among populations and regions & 1.6 & 0.016 & $<0.0001$ \\
\hline & Within populations & 98.55 & 0.014 & $<0.0001$ \\
\hline \multicolumn{5}{|l|}{ Regions } \\
\hline \multirow{3}{*}{$\begin{array}{l}\text { North; Southwest; Southeast } \\
\text { (North: JPN, HAW; Southwest: AUS, TAW; } \\
\text { Southeast: MEX, ECU) }\end{array}$} & Among regions & 0.70 & 0.007 & 0.008 \\
\hline & Among populations and regions & 0.82 & 0.008 & $<0.0001$ \\
\hline & Within populations & 98.48 & 0.152 & $<0.0001$ \\
\hline \multirow{3}{*}{$\begin{array}{l}\text { North; MEX; ECU; (AUS, TAW) } \\
\text { (North: JPN, HAW, CAL) }\end{array}$} & Among regions & 0.75 & 0.008 & 0.038 \\
\hline & Among populations and regions & 0.76 & 0.008 & $<0.0001$ \\
\hline & Within populations & 98.48 & 0.015 & $<0.0001$ \\
\hline \multirow{3}{*}{$\begin{array}{l}\text { North; MEX; ECU; AUS } \\
\text { (North: JPN, HAW, CAL, TAW) }\end{array}$} & Among regions & 1.28 & 0.012 & $<0.0001$ \\
\hline & Among populations and regions & 0.40 & 0.004 & $<0.0001$ \\
\hline & Within populations & 98.32 & 0.017 & $<0.0001$ \\
\hline
\end{tabular}

Note: Significance was assessed using 10100 permutations. See Table 1 for location abbreviations.

other samples separate resulted in a $\Phi_{\mathrm{CT}}=0.034(P<$ 0.0001; Table 4).

\section{Migration and effective population size}

The average $\Theta$ values estimated with the MIGRATE software for the microsatellite data set ranged from 0.2923 $(\mathrm{SE}=0.0277)$ in AUS to $1.0512(\mathrm{SE}=0.1258)$ in JPN (Fig. 4). The estimates of per generation immigration rates were also variable among samples (only values $>20$ are shown in Fig. 4 to facilitate presentation of data). Analysis of the historical migration rate $(M)$ indicates that gene flow has historically been asymmetrical, and JPN has been the most important contributor to gene flow. For JPN, TAW, and ECU, mutation has likely been more important than gene flow for introducing variation into the population, while gene flow appears to have been more important for bringing new alleles into MEX and CAL. Interestingly, AUS appears to have received immigrants from the North
Pacific, but has been an important source of immigrants for CAL and MEX in the eastern Pacific.

\section{Discussion}

\section{Stock structure}

The results of the AMOVA and PCA analyses clearly delineate the presence of at least four genetically discrete groups of striped marlin within the Pacific Ocean, which correspond to the four described striped marlin spawning areas. As with previous genetic studies, our results show genetic homogeneity between temporal replicates, indicating that the observed genetic heterogeneity among samples from different locations reflects geographical differences in the genetic structure rather than sampling error. For the microsatellite data, a locus-by-locus analysis shows that the observed structure was not driven by any single locus or pair of loci (data not shown). These results are corroborated by 


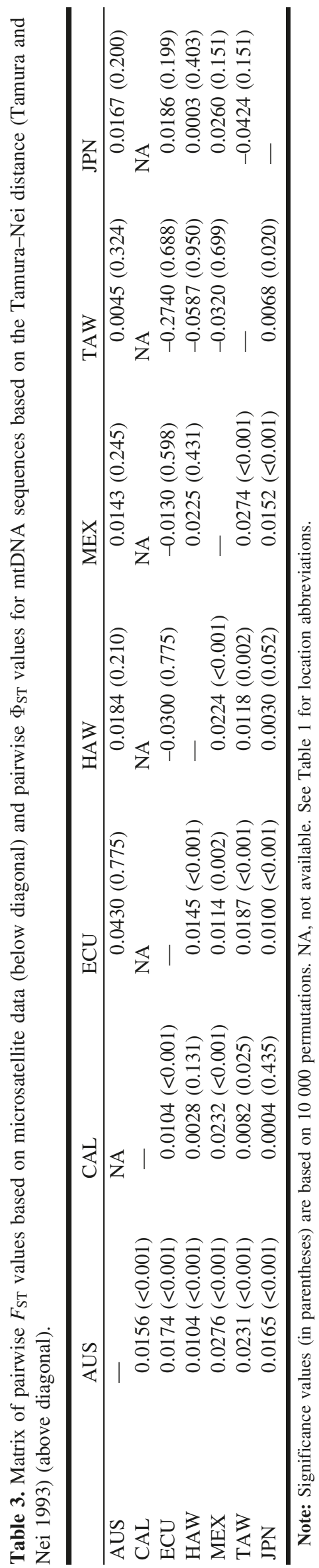

our observation of population structure based on data from the mtDNA locus and suggest the presence of a minimum of four long-term, temporally stable genetic stocks of striped marlin in the Pacific Ocean.

In the southwest Pacific, our temporal samples spanning 11 years off Port Stephens, Australia, suggest that genetic variation in striped marlin is temporally stable, at least in this area. Pairwise comparisons of the AUS collection with other all collections were highly significant, and the AUS collections were clearly separated from the other collections in the PCA analysis. These results are consistent with other fisheries data. Striped marlin are known to spawn off eastern Australia based on the presence of larvae. In addition, tagging data shows that the majority of striped marlin released off Australia are recaptured within several hundred nautical miles $(1 \mathrm{n} . \mathrm{m} .=1.852 \mathrm{~km})$ of release even after 6-9 months at liberty and have a mean displacement of 200 n.m., suggesting that striped marlin in this area are residential (Ortiz et al. 2003). Additionally, no tag-recaptures of marlin released in the southwest Pacific have been recorded in the eastern Pacific or vice versa (Ortiz et al. 2003).

Like the southwest Pacific, the ECU collection in the southeast Pacific was significantly different from all other samples based on microsatellite data. Pairwise $F_{\mathrm{ST}}$ comparisons between ECU and other samples were all significant, and as with previous studies (Graves and McDowell 1994), ECU was distinct from the eastern Pacific (MEX) collection. Tagging studies have indicated that movements in the southeast Pacific are complex, but that there is a general movement towards the Galapagos and southern Central American coastline, which then expands offshore and southwest in October-March. This has been correlated to the migration of mature individuals towards the spawning grounds (Kume and Joseph 1969), as over $75 \%$ of fish caught in this area at this time are mature, and supports the lack of mixing indicated by genetic data.

Several lines of evidence support the genetic clustering of the northern striped marlin samples (JPN, HAW, TAW, and CAL). The striped marlin has a continuous horseshoeshaped distribution with one arm that extends across the North Pacific. Tag-recapture data have shown movements into the area around Hawaii by predominantly 40-60 kg striped marlin migrating from Californian coastal waters from late autumn - early winter. However, there have been no California recaptures of striped marlin tagged in Hawaii (Ortiz et al. 2003), nor are fish in spawning condition caught off the coast of California. Whether there is movement between the central North Pacific (HAW) and western Pacific (JPN, TAW) is unknown because there has been negligible tagging effort in the northeast Pacific. However, although striped marlin spawn in the region southeast of Japan (Squire and Suzuki 1990), few juveniles are caught in this area and it has been suggested that they may migrate from this region, returning when they become mature (Bromhead et al. 2004). This supposition is supported by the fact that juvenile striped marlin appear in the central North Pacific at around $10 \mathrm{~kg}$, and neither larger fish nor larvae are found in this area, suggesting that juveniles use the central North Pacific as a feeding ground (Matsumoto and Kazama 1974). Taken together, these data imply that juvenile striped marlin spawned off Japan may be moving east into the central 
Fig. 3. Principal component analysis (PCA) showing the genetic relationship among striped marlin (Kajikia audax). PCA axis 1 explains $29.81 \%$ of the variance; axis 2 explains $20.86 \%$ of the variance. Circles are drawn around groups of collections based on results of pairwise $F_{\text {ST }}$ values; nonsignificant comparisons are grouped.

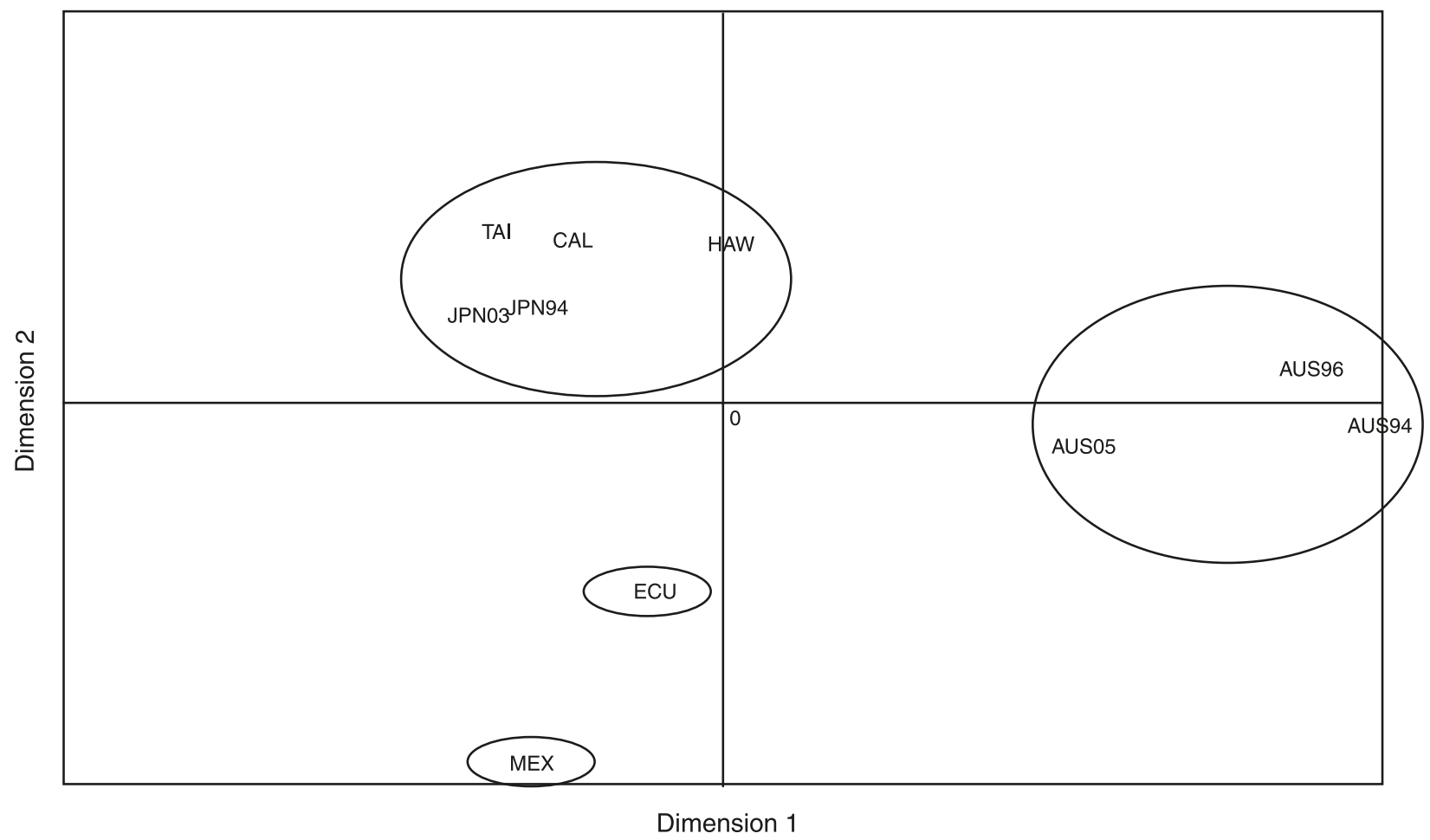

Table 4. Analysis of molecular variance (AMOVA) among regions and locations for striped marlin (Kajikia audax) collections based on mtDNA data.

\begin{tabular}{|c|c|c|c|c|}
\hline & Source of variation $\left(\Phi_{\mathrm{ST}}\right)$ & $\%$ variation & $\begin{array}{l}\text { Fixation } \\
\text { index }\end{array}$ & $P$ \\
\hline \multirow[t]{2}{*}{ All samples } & Among samples & -0.67 & -0.007 & 0.642 \\
\hline & Within samples & 100.67 & - & - \\
\hline \multirow[t]{3}{*}{ (JPN, TAW, HAW); (MEX, ECU); AUS } & Among regions & 3.14 & 0.031 & $<0.0001$ \\
\hline & Among populations and regions & -2.77 & -0.029 & 0.710 \\
\hline & Within populations & 99.63 & 0.004 & 0.623 \\
\hline \multirow[t]{3}{*}{ (JPN, HAW, TAW); MEX; ECU; AUS } & Among regions & 3.40 & 0.034 & $<0.0001$ \\
\hline & Among populations and regions & -3.12 & -0.032 & 0.377 \\
\hline & Within populations & 99.71 & 0.003 & 0.633 \\
\hline \multirow[t]{3}{*}{ (JPN, TAW); MEX; ECU; AUS; HAW } & Among regions & 4.31 & 0.043 & $<0.0001$ \\
\hline & Among populations and regions & -4.39 & -0.046 & 0.286 \\
\hline & Within populations & 100.08 & -0.001 & 0.637 \\
\hline \multirow[t]{3}{*}{ (JPN, TAW); (MEX, ECU); AUS; HAW } & Among regions & 3.47 & 0.035 & 0.005 \\
\hline & Among populations and regions & - & -3.49 & -0.036 \\
\hline & Within populations & 100.02 & -0.000 & 0.632 \\
\hline
\end{tabular}

Note: $\Phi_{\mathrm{ST}}$ was calculated based on Tamura-Nei distance (Tamura and Nei 1993). Significance was assessed using 10100 permutations. The two years of JPN data were held separately in this analysis, although they are represented as a single year below. See Table 1 for location abbreviations.

Pacific to feed and that some of these fish may end up off the coast of California before returning to the spawning grounds off Japan.

Although the TAW samples grouped most closely with the other northern samples and no significant $\Phi_{\mathrm{ST}}$ differences were noted between TAW and other northern samples based on mtDNA data, microsatellite data revealed small but significant pairwise differences between TAW and CAL and between TAW and JPN. Striped marlin larvae have been found in the eastern Indian Ocean off the northwest coast of Australia (Nakamura 1983) as well as in the Timor and Banda seas (Ueyanagi and Wares 1975). Derivation of the TAW samples from a mixture of both the Indian Ocean and western North Pacific spawning stocks is one possible explanation for the observed differences, and the relationship between Pacific Ocean and Indian Ocean striped marlin should be examined further in future studies.

One of the most interesting results of the current study is 
Fig. 4. Historical effective population size $(\Theta)$ and migration rate scaled by mutation $(M)$ between populations, including the standard errors across the five runs using the program MIGRATE (Beerli and Felsenstein 2001). Values of $M$ less than 20 are not shown. See Table 1 for location abbreviations.

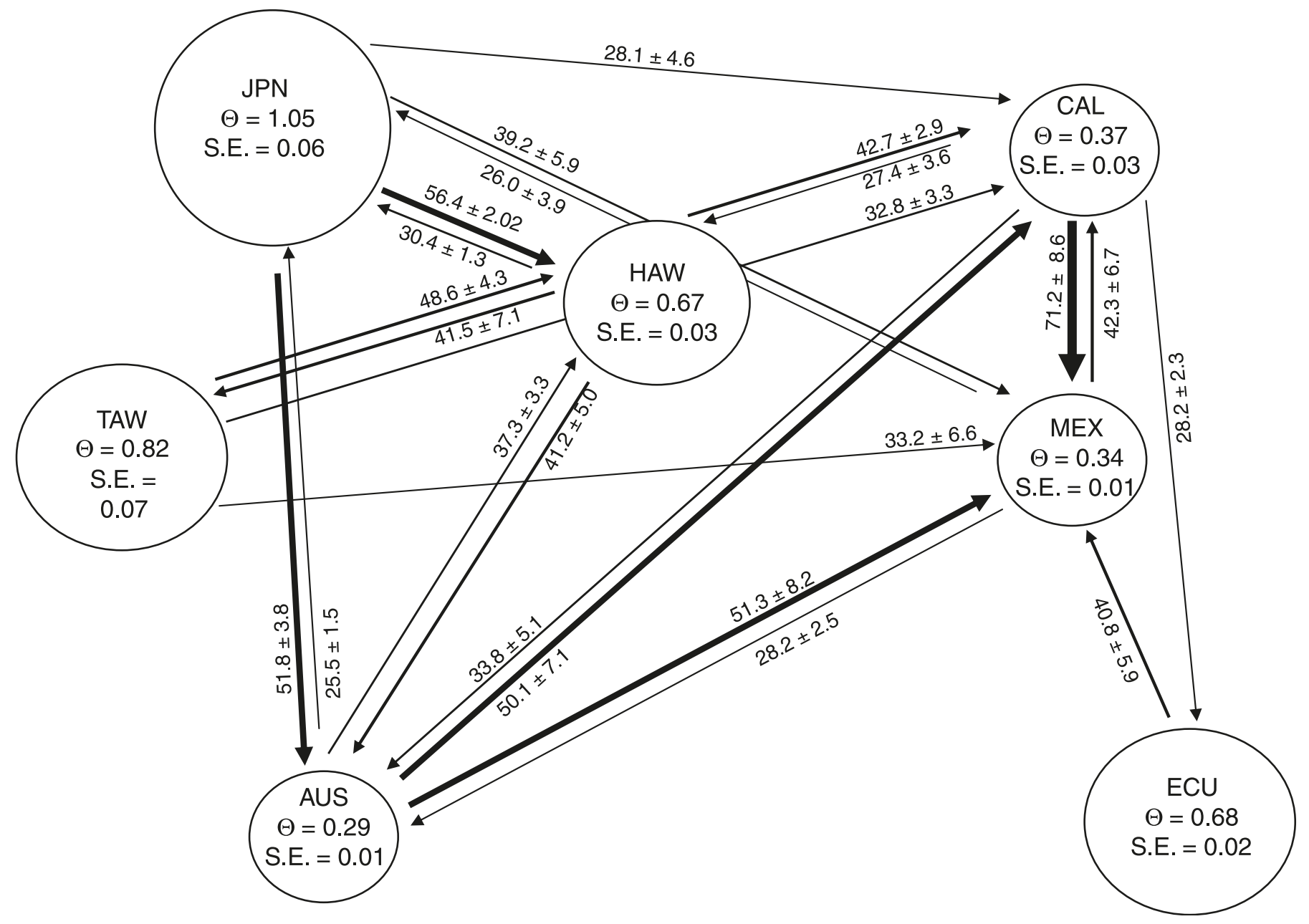

the presence of statistically significant differences between striped marlin taken off California (CAL) and those taken off Baja California (MEX), despite the fact that tagging studies clearly demonstrate migration between these areas. Movements of Mexican fish northward towards California during the summer months have been documented (e.g., Armas et al. 1999), and most tagged southern California fish are recaptured off Baja California (Ortiz et al. 2003). In addition, longline data show that fluctuations in catch rates in the Baja California region are correlated with fluctuations in the rest of the eastern Pacific, suggesting considerable mixing within this area (Squire and Au 1990). Although our results could be due to sampling error associated with insufficient sample size, there are data to support our finding. In the Northeast Pacific off Baja California, 65\% of fish caught are mature (Squire and Suzuki 1990), while no fish in spawning condition are caught off the coast of California (M. Hinton, Inter-American Tropical Tuna Commission, 8604 La Jolla Shores Drive, La Jolla, California, personal communication, 2006). In addition, most striped marlin recaptured off Baja California are caught within a few hundred nautical miles of release even after nearly 2 years at liberty (Ortiz et al. 2003). Perhaps the most con- vincing support for validity of results suggesting that the MEX and CAL collections are representative of distinct populations is based on data from satellite tagging. Since 2000, 115 satellite tags have been put on striped marlin near Magdelena Bay, Baja California, Mexico. Although they have been tracked for up to 9 months (NovemberJuly), none have been found to range from Mexican waters (M. Domeier, Pfleger Institute of Environmental Research, Oceanside, California, personal communication). Taken together, the available data suggest the presence of a selfsustaining resident population of striped marlin off the coast of Mexico. Since it is thought that striped marlin off the coast of California are composed of subadult fish that are thought to travel to spawning grounds in the western Pacific upon maturity, it seems plausible that striped marlin from both stocks mix on offshore feeding grounds. This mixing could explain the apparent conflict between the genetic and conventional tagging data. Other large pelagic species, most notably the bluefin tuna (Thunnus thynnus), have recently been shown to mix on feeding grounds but maintain distinct stocks driven by spawning site fidelity (Carlsson et al. 2006).

Microsatellite data are capable of detecting small genetic 
differences between populations because of their high mutation rate. This has led to the realization that statistically significant differences between populations do not always indicate biologically significant differences (Waples 1998; Hedrick 1999). However, the results of this study correlate well with the other fishery data; the seemingly cyclical movements of adults with season combined with the presence of distinct spawning grounds. In addition, just over $60 \%$ of global recaptures of tagged striped marlin occur within 200 n.m. of the release point, and $84 \%$ occur within 500 n.m., while less than $8 \%$ are recaptured over 1000 n.m. from the point of release, indicating at least some level of regional fidelity (Ortiz et al. 2003; Bromhead et al. 2004). There are also morphological differences between northern and southern Pacific striped marlin; southern fish are larger than northern fish and there are differences in pectoral fin length (Ueyanagi and Wares 1975). Finally, analysis of longline data has shown that catch rates of striped marlin near the equator in the western Pacific are exceptionally low, which further implies the potential for separate northern and southern stocks particularly in the west (Ueyanagi and Wares 1975).

\section{Historical migration and effective population size}

Examination of the asymmetric matrix of historical migration rates and relative effective population size estimates suggest historical patterns that are not apparent using traditional genetic analyses. Although no genetic differentiation was noted among TAW, JPN, HAW, and CAL, estimates of long-term effective population sizes $(\Theta)$ in these samples ranged from 1.05 to 0 . 37 . This discrepancy may result from sampling different components of the population in the different areas; mature fish are not found in HAW or CAL, and the effective population sizes in these areas may appear smaller owing to the exclusion of some age classes. Alternately, striped marlin may have arisen in the western Pacific and subsequently spread eastward to HAW and CAL, although this might be expected to result in fewer alleles per locus in the HAW and CAL samples, which was not evident in this study. Finally, the larger effective population sizes of the JPN and TAW samples may be due to immigration from other (Indian Ocean) source populations not included in this study, and the more immigrants from the unknown populations that are arriving in the sample populations, the more inflated the estimated population sizes (Beerli 2004).

Interestingly, estimates of $\Theta$ suggest that the relative long-term inbreeding effective population size of the CAL and MEX samples are nearly identical $(0.377$ vs. 0.337 , respectively) and that of all pairwise comparisons, these two samples have historically had the largest exchange of migrants between them ( 71 and 43 , respectively), suggesting that they comprise two samples from a single population. This corroborates the observed movements of fish between the two areas seen in tagging studies (Armas et al. 1999; Ortiz et al. 2003) but is contrary to the results of both the satellite tagging data (M. Domeier, Pfleger Institute of Environmental Research, Oceanside, California, personal communication) and the finding that these samples are genetically distinct. The discrepancy between the high level of historical exchange and an apparent lack of contemporane- ous gene flow is intriguing. If a subset of the samples taken from each location actually belonged to the other stock (some samples were taken at a time and place when stocks were mixed on feeding grounds), the apparent high level of historical migration could simply be an artifact and this seems the most likely scenario. This highlights the need for further study of population structure in striped marlin, as samples used in this study were taken from adult specimens of unknown natal origin rather from juveniles. Recent studies of bluefin tuna (Carlsson et al. 2004) and loggerhead turtles, Caretta caretta, (Bowen et al. 2005) have demonstrated that fine-scale population structure may not be fully elucidated by examination of a single life-history stage, and population structure may in fact be obscured by improper sampling.

Results of our study suggest that striped marlin comprises multiple genetic stocks. Northern collections of striped marlin taken from Japan, Taiwan, Hawaii, and California appear to constitute a single genetic stock, while southern collections from Australia, Mexico, and Ecuador are statistically significantly different from each other as well as from the northern samples. These genetic stocks correspond well with the known distribution of larvae and provide support for the idea that striped marlin either exhibit spawning site fidelity and (or) are less migratory than other billfishes. Future studies of striped marlin should include more collection locations as well as more temporal replicates and surveys at spawning grounds, as they may reveal the presence of additional genetic stock structure. The presence of genetically independent stocks should be factored into management and conservation decisions impacting striped marlin.

\section{Acknowledgements}

We thank Michael Hinton and Jens Carlsson for helpful comments and suggestions. We also thank Sandra Boles and Jeanette Carlsson for technical assistance. We are indebted to Ed Everett, Julian Pepperell, Narishito Chow, Dave Holts, and the staff of the Hotel Spa Buenavista for providing samples. This study was supported by grants from NOAANMFS and is Virginia Institute of Marine Science, College of William and Mary Contribution No. 2934.

\section{References}

Armas, R.G., Sosa-Nishizaki, O., Rodriguez, R.F., and Perez, V.A.L. 1999. Confirmation of the spawning area of the striped marlin, Tetrapturus audax, in the so-called core area of the eastern tropical Pacific off Mexico. Fish. Oceanogr. 8: 238-242. doi:10.1046/j.1365-2419.1999.00102.x.

Beerli, P. 2002. MIGRATE-N: estimation of population sizes and gene flow using the coalescent. Available from popgen.scs.fsu. edu/Migrate-n.html [accessed 8 May 2008].

Beerli, P. 2004. Effect of unsampled populations on the estimation of population sizes and migration rates between sampled populations. Mol. Ecol. 13: 827-836. doi:10.1111/j.1365-294X.2004. 02101.x. PMID:15012758.

Beerli, P., and Felsenstein, J. 2001. Maximum likelihood estimation of a migration matrix and effective population sizes in $n$ subpopulations by using a coalescent approach. Proc. Natl. Acad. Sci. U.S.A. 98: 4563-4568. doi:10.1073/pnas.081068098. PMID: 11287657.

Bowen, B.W., Bass, A.L., Soares, L., and Toonen, R.J. 2005. Con- 
servation implications of complex population structure: lessons from the loggerhead turtle Caretta caretta. Mol. Ecol. 14: 2389-2402. doi:10.1111/j.1365-294X.2005.02598.x. PMID: 15969722.

Bromhead, D., Pepperell, J., Wise, B., and Findlay, J. 2004. Striped marlin: biology and fisheries. Bureau of Rural Science, Canberra. ISBN:0642475938.

Buonaccorsi, V.P., and Graves, J.E. 2000. Isolation and characterization of novel polymorphic tetra-nucleotide microsatellite markers from the blue marlin, Makaira nigricans. Mol. Ecol. 9: 820-821. doi:10.1046/j.1365-294x.2000.00915-2.x. PMID: 10849299.

Buonaccorsi, V.P., Morgan, L., Reece, K.S., and Graves, J.E. 1999. Geographic distribution of molecular variance within blue marlin Makaira nigricans: a hierarchical analysis of allozyme, single copy nuclear DNA, and mitochondrial DNA markers. Evolution, 53: 568-579. doi:10.2307/2640793.

Buonaccorsi, V.P., McDowell, J., and Graves, J.E. 2001. Reconciling patterns of inter-ocean molecular variance from four classes of molecular markers in blue marlin Makaira nigricans. Mol. Ecol. 10: 1179-1196. doi:10.1046/j.1365-294X.2001.01270.x. PMID:11380876.

Carlsson, J., McDowell, J.R., Diaz-Jaimes, P., Carlsson, J.E.L., Boles, S.B., Gold, J.R., and Graves, J.E. 2004. Microsatellite and mitochondrial DNA analyses of Atlantic bluefin tuna (Thunnus thynnus thynnus) population structure in the Mediterranean Sea. Mol. Ecol. 13: 3345-3356. doi:10.1111/j.1365294X.2004.02336.x. PMID:15487994.

Carlsson, J., McDowell, J.R., Carlsson, J.E.L., and Graves, J.E. 2006. Genetic identity of YOY bluefin tuna from eastern and western Atlantic spawning areas. J. Hered. 98: 23-28. doi:10. 1093/jhered/es1046. PMID:17158466.

Estoup, A., Largiader, C.R., Perrot, E., and Chourrout, D. 1996. Rapid one-tube DNA extraction for reliable PCR detection of fish polymorphic markers and transgenes. Mol. Mar. Biol. Biotechnol. 5: 295-298.

Excoffier, L., Smouse, P.E., and Quattro, J.M. 1992. Analysis of molecular variance inferred from metric distances among DNA haplotypes: application of human mitochondrial DNA restriction data. Genetics, 147: 915-925.

Excoffier, L., Laval, G., and Schneider, S. 2005. Arlequin ver. 3.0: An integrated software package for population genetics data analysis. Evol. Bioinf. Online, 1: 47-50.

Falterman, B.J. 1999. Indo-Pacific population structure of the black marlin, Makaira indica, inferred from molecular markers. M.Sc. thesis, Department of Fisheries Science, Virginia Institute of Marine Science, School of Marine Science, College of William and Mary, Gloucester Point, Va.

Finnerty, J.K., and Block, B.A. 1992. Direct sequencing of mitochondrial DNA detects highly divergent haplotypes in blue marlin (Makaira nigricans). Mol. Mar. Biol. Biotechnol. 1: 200211.

Goudet, J. 1995. FSTAT (version 1.2): a computer program to calculate F-statistics. J. Hered. 86: 485-486.

Guo, S.W., and Thompson, E.A. 1992. Performing the exact-test for Hardy-Weinburg proportion for multiple alleles. Biometrics, 48: 361-372. doi:10.2307/2532296. PMID:1637966.

Graves, J.E. 1998. Molecular insights into the population structures of cosmopolitan marine fishes. J. Hered. 89: 427-437. doi:10. 1093/jhered/89.5.427.

Graves, J.E., and McDowell, J.R. 1994. Genetic analysis of striped marlin (Tetrapturus audax) population structure in the Pacific Ocean. Can. J. Fish. Aquat. Sci. 51: 1762-1768. doi:10.1139/ f94-177.
Graves, J.E., and McDowell, J.R. 1995. Inter-ocean genetic divergence of istiophorid billfishes. Mar. Biol. (Berl.), 122: 193-204.

Graves, J.E., and McDowell, J.R. 2001. A genetic perspective on the stock structures of blue marlin and white marlin in the Atlantic Ocean. Coll. Vol. Sci. Papers. ICCAT, 53: 180-187.

Graves, J.E., and McDowell, J.R. 2003. Population structure of the world's istiophorid billfishes: a genetic perspective. Mar. Freshw. Res. 54: 287-298. doi:10.1071/MF01290.

Graves, J.E., and McDowell, J.R. 2006. Genetic analysis of white marlin (Tetrapturus albidus) stock structure. Bull. Mar. Sci. 79: 469-482.

Hedrick, P.W. 1999. Highly variable genetic loci and their interpretation in evolution and conservation. Evolution, 53: 313-318. doi:10.2307/2640768.

Hinton, M.G., and Maunder, M.N. 2003. Status of striped marlin in the eastern Pacific Ocean in 2002 and outlook for 2003-2004. Report 4. Inter-American Tropical Tuna Commission, La Jolla, Calif.

Hudson, R.R. 2000. A new statistic of detecting genetic differentiation. Genetics, 155: 2001-2014.

King, D.M. 1990. Economic trends affecting commercial billfish fisheries In Planning the Future of Billfishes. Research and Management in the 90's and Beyond. Proceedings of the 2nd International Billfish Symposium, Kailua-Kona, Hawaii, 15 August 1988. Part 2. Edited by R.H. Stroud. National Coalition for Marine Conservation, Leesburg, Va. pp. 89-102.

Kume, S., and Joseph, J. 1969. Size composition and sexual maturity of billfish caught by the Japanese longline fishery in the Pacific Ocean east of 130W. Bull. Far Seas Fish. Res. Lab. 2: 115-162.

Matsumoto, W.M., and Kazama, T.K. 1974. Occurrence of young billfishes in the Central Pacific Ocean. In Proceedings of the International Billfish Symposium Kailua-Kona, Hawaii, 912 August 1972. Part 2. Edited by R.S. Shomura and F. Williams. National Marine Fisheries, Service, Seattle, Wash. NOAA Tech. Rep. NMFS SSRF-675. pp. 238-247.

Morgan, L.W. 1992 Allozyme analysis of billfish population structure. M.Sc. thesis, Department of Fisheries Science, Virginia Institute of Marine Science, School of Marine Science, College of William and Mary, Gloucester Point, Va.

Nakamura, I. 1983. Systematics of billfishes (Xiphiidae and Istiophoridae). Publ. Seto Mar. Biol. Lab. 28: 255-396.

Nakamura, I. 1985. FAO species catalogue. Vol. 5. Billfishes of the world. An annotated and illustrated catalogue of marlins, sailfishes, spearfishes and swordfishes known to date. FAO Fisheries Synopses 125, Rome, Italy.

Ortiz, M., Prince, E.D., Serafy, J.E., Holts, D.B., Davy, K.B., Pepperell, J.G., Lowry, M.B., and Holdsworth, J.C. 2003. A global overview of the major constituent-based billfish tagging programs and their results since 1954. Mar. Freshw. Res. 54: 489-507. doi:10.1071/MF02028.

Palumbi, S.R., Martin, A., and Romano, S. McMillan, W.O., Stice, L., and Grabowski, G. 1996. The simple fool's guide to PCR. Kewalo Marine Laboratory and University of Hawaii, Honolulu, Hawaii.

Penrith, M.J., and Cram, D.L. 1974. The Cape of Good Hope: a hidden barrier to billfishes. In Proceedings of the International Billfish Symposium Kailua-Kona, Hawaii, 9-12 August 1972. Part 2. Edited by R.S. Shomura and F. Williams. National Marine Fisheries Service, Seattle, Wash. NOAA Tech. Rep. NMFS SSRF-675. pp. 175-187.

Raymond, M., and Rousset, F. 1995. GENEPOP (version 1.2) population genetics software for exact test and ecumenicism. J. Hered. 86: 248-249. 
Rice, W.R. 1989. Analyzing tables of statistical tests. Evolution, 43: 223-225. doi:10.2307/2409177.

Rozas, J., Sánchez-DelBarrio, J.C., Messeguer, X., and Rozas, R. 2003. DnaSP, DNA polymorphism analyses by the coalescent and other methods. Bioinformatics, 19: 2496-2497. doi:10. 1093/bioinformatics/btg359. PMID:14668244.

Saitou, N., and Nei, M. 1987. The neighbor-joining method: a new method for reconstructing phylogenetic trees. Mol. Biol. Evol. 4: 406-425. PMID:3447015.

Sambrook, J., and Russell, D.W. 2001. Molecular cloning: a laboratory manual. 3rd ed. Cold Spring Harbor Laboratory Press, Cold Spring Harbor, N.Y.

Seutin, G., White, B.N., and Boag, P.T. 1991. Preservation of avian blood and tissue samples for DNA analysis. Can. J. Zool. 69: 82-90. doi:10.1139/z91-013 .

Skillman, R.A. 1990. Stock identification and billfish management. In Planning the Future of Billfishes: Research and Management in the 90's and Beyond. Proceedings of the 2nd International Billfish Symposium, Kailua-Kona, Hawaii, 1-5 August 1988. Part 2. Edited by R.H. Stroud. National Coalition for Marine Conservation, Leesburg, Va. pp. 207-213.

Smedbol, R.K., McPerson, A., Hansen, M.M., and Kenchington, E. 2002. Myths and moderation in marine 'metapopulations'? Fish Fish. Ser. 3: 20-35.

Squire, J.L., and Au, D.K.W. 1990. Striped marlin in the north-east Pacific - a case for local depletrion and core area management. In Planning the Future of Billfishes: Research and Management in the 90's and Beyond. Proceedings of the 2nd International Billfish Symposium, Kailua-Kona, Hawaii, 1-5 August 1988. Part 2. Edited by R.H. Stroud. National Coalition for Marine Conservation, Leesburg, Va. pp. 199-214.

Squire, J.L., Jr., and Suzuki, Z. 1990. Migration trends of striped marlin (Tetrapturus audax) in the Pacific Ocean. In Planning the Future of Billfishes: Research and Management in the 90's and Beyond. Proceedings of the 2nd International Billfish
Symposium, Kailua-Kona, Hawaii, 1-5 August 1988. Part 2. Edited by R.H. Stroud. National Coalition for Marine Conservation, Leesburg, Va. pp. 67-80.

Swofford, D.L. 2000. PAUP*. Phylogenetic analysis using parsimony (*and other methods). Version 4. Sinauer Associates, Sunderland, Mass.

Talbot, F.H., and Penrith, M.J. 1962. Tunnies and marlins of South Africa. Nature (London), 193: 558-559. doi:10.1038/193558a0.

Tamura, K., and Nei, M. 1993. Estimation of the number of nucleotide substitutions in the control region of mitochondrial DNA in humans and chimpanzees. Mol. Biol. Evol. 10: 512 526. PMID:8336541.

Thompson, J.D., Higgins, D.G., and Gibson, T.J. 1994. CLUSTAL W: improving the sensitivity of progressive multiple sequence alignment through sequence weighting, position-specific gap penalties and weight matrix choice. Nucleic Acids Res. 22: 4673-4680. doi:10.1093/nar/22.22.4673. PMID:7984417.

Ueyanagi, S., and Wares, P.G. 1975. Synopsis of biological data on striped marlin, Tetrapturus audax (Philippi, 1887). In Proceedings of the International Billfish Symposium, Kailua-Kona, Hawaii, 9-12 August 1972, Part 3. Species synopses. Edited by R.S. Shomura and F. Williams. National Marine Fisheries, Service, Seattle, Wash. NOAA Tech. Rep. NMFS SSRF-675. pp. 132-159.

van Oosterhout, C., Hutchinson, W.F., Wills, D.P.M., and Shipley, P. 2004. MICRO-CHECKER: software for identifying and correcting genotyping errors in microsatellite data. Mol. Ecol. Notes, 4: 535-538. doi:10.1111/j.1471-8286.2004.00684.x.

Waples, R.S. 1998. Separating wheat from the chaff: patterns of genetic differentiation in high gene flow species. J. Hered. 89: 438-450. doi:10.1093/jhered/89.5.438.

Weir, B.S., and Cockerham, C.C. 1984. Estimating F-statistics for the analysis of population structure. Evolution, 38: 1358-1370. doi:10.2307/2408641. 